Revista Eletrônica de Direito Processual - REDP. Volume 16. Julho a dezembro de 2015

Periódico Semestral da Pós-Graduação Stricto Sensu em Direito Processual da UERJ

Patrono: José Carlos Barbosa Moreira. ISSN 1982-7636. pp. 550-579 http://www.e-publicacoes.uerj.br/index.php/redp/index

\title{
A DEFENSORIA PÚBLICA NO NOVO CÓDIGO DE PROCESSO CIVIL ${ }^{1}$
}

\section{THE PUBLIC DEFENDER OFFICE IN THE NEW CIVIL PROCEDURE CODE}

Renan Barros dos Reis

Pós-Graduado em Direito Processual pela Universidade Estadual do Piauí (UESPI). Defensor Público de $1^{\text {a }}$ Classe na Defensoria Pública do Estado do Maranhã (DPE-MA). renangen@globo.com

RESUMO: Trata-se de estudo objetivo e descritivo acerca das principais previsões do Novo Código de Processo Civil sobre a Defensoria Pública, bem como suas influências e consequências na atuação do Defensor Público dentro do processo judicial cível. Partindo da análise da Defensoria Pública como instituição essencial à justiça com a função de promover os direitos dos necessitados, o estudo se propõe a abordar a importância da instituição como sujeito autônomo do processo, sua função como curadora especial, assim como sistematizar as prerrogativas e responsabilidades do Defensor Público no Novo Código de Processo Civil.

PalaVRaS-Chave: Novo Código de Processo Civil; Defensoria Pública; Sujeitos do Processo; Curadoria Especial; Prerrogativas; Deveres; Responsabilidades.

\begin{abstract}
It is objective and descriptive study about the main forecasts of the New Code of Civil Procedure on the Public Defender Office, as well as their influences and consequences in the work of the Public Defender in the civil lawsuit. Starting from the analysis of the Public Defender Office as essential to justice institution with the task of promoting the rights of the needy, the study is to discuss the importance of the institution as a subject standalone process, its function as a special curator, as well as systematize the prerogatives and responsibilities of Public Defender in the New Code of Civil Procedure.
\end{abstract}

\footnotetext{
${ }^{1}$ Artigo recebido em 21/03/2015 e aprovado em 22/11/2015.
} 
Revista Eletrônica de Direito Processual - REDP. Volume 16. Julho a dezembro de 2015

Periódico Semestral da Pós-Graduação Stricto Sensu em Direito Processual da UERJ

Patrono: José Carlos Barbosa Moreira. ISSN 1982-7636. pp. 550-579 http://www.e-publicacoes.uerj.br/index.php/redp/index

KEYWORDS: New Code of Civil Procedure ; Public Defender Office; Subject of Procedure; Special Curated; Prerogatives; Duties; Responsibilities.

\section{INTRODUÇÃO}

Em 16 de março de 2015 foi publicada a Lei $n^{\circ}$ 13.105, que instituiu o Novo Código de Processo Civil (NCPC), o qual foi concebido, gestado e nascido sob a égide da Constituição da República de 1988, ou seja, em um Estado Democrático de Direito. Tratase de um código democrático e plural, o qual absorveu em seu conteúdo boa parte dos anseios das instituições que trabalham no dia-a-dia com processos judiciais, entre os quais se encontram a Defensoria Pública.

O presente artigo visa, assim, a sistematizar as principais previsões acerca da Defensoria Pública no NCPC, assim como analisá-las no contexto constitucionaldemocrático cuja Defensoria Pública se insere, esforçando-se para objetivamente restringir ao máximo o âmbito de incidência ao processo judicial cível. Tendo sempre por base a primazia da Defensoria como instituição voltada precipuamente à defesa dos hipossuficientes, ou seja, daqueles que não podem, sem sacrificar seu patrimônio, custear um advogado, verificar-se-á se tais previsões são inovações no ordenamento jurídico ou organização de regras já existentes, assim como as possíveis consequências, positivas ou negativas, que tais dispositivos possam gerar.

Não se pode negar que a maioria das disposições da recente lei adjetiva civil já existia em outras leis ou em entendimentos jurisprudenciais. Ademais, algumas previsões não tiveram maiores consequências práticas a ponto de merecerem referência.

Porém, a codificação e previsão de garantias e institutos atinentes à Defensoria Pública elevam a instituição, de modo que a enraíza no meandro das legislações nacionais e solidifica-a, cada vez mais, em patamar isonômico com as demais instituições essenciais à função jurisdicional, harmonizando a figura da Defensoria Pública como sujeito do processo civil.

Assim, sobressai a necessidade de expor objetivamente sobre o impacto que o regramento do novo Código de Processo Civil tem sobre a Defensoria Pública, bem como as possibilidades daí surgidas, na medida da importância das previsões e inovações da lei adjetiva. 
Revista Eletrônica de Direito Processual - REDP. Volume 16. Julho a dezembro de 2015

Periódico Semestral da Pós-Graduação Stricto Sensu em Direito Processual da UERJ

Patrono: José Carlos Barbosa Moreira. ISSN 1982-7636. pp. 550-579 http://www.e-publicacoes.uerj.br/index.php/redp/index

\section{A DEFENSORIA PÚBLICA E A DEFESA DOS NECESSITADOS}

Desde a Constituição de 1988 a Defensoria Pública é a instituição constitucionalmente incumbida da defesa judicial e extrajudicial dos necessitados, também chamados hipossuficientes. Desenvolveu-se e solidificou-se como órgão autônomo no decorrer dos anos e, fruto de vitória da democracia no atual cenário brasileiro, teve sua ampliação com a promulgação da Emenda Constitucional no 80, em 04 de junho de 2014, que deu nova redação ao art. 134 da Constituição da República de 1988, indicando-a como instituição permanente (princípio da perenidade) e de promoção dos direitos humanos.

Dispõe o citado artigo:

Art. 134. A Defensoria Pública é instituição permanente, essencial à função jurisdicional do Estado, incumbindo-lhe, como expressão e instrumento do regime democrático, fundamentalmente, a orientação jurídica, a promoção dos direitos humanos e a defesa, em todos os graus, judicial e extrajudicial, dos direitos individuais e coletivos, de forma integral e gratuita, aos necessitados, na forma do inciso LXXIV do art. $5^{\circ}$ desta Constituição Federal.

Discorrendo sobre a Defensoria Pública, o Supremo Tribunal Federal, no julgamento da $\mathrm{ADI} n^{\circ}$ 2903/PB², da lavra do eminente Ministro Celso de Mello, asseverou a importância da Defensoria Pública como instituição essencial à Justiça, cujo trecho restou assim ementado:

\section{DEFENSORIA PÚBLICA - RELEVÂNCIA - INSTITUIÇÃO PERMANENTE ESSENCIAL À FUNÇÃO JURISDICIONAL DO ESTADO - O DEFENSOR PÚBLICO COMO AGENTE DE CONCRETIZAÇÃO DO ACESSO DOS NECESSITADOS À ORDEM JURÍDICA}

- A Defensoria Pública, enquanto instituição permanente, essencial à função jurisdicional do Estado, qualifica-se como instrumento de

\footnotetext{
${ }^{2}$ STF - ADI: 2903/PB, Relator: Min. CELSO DE MELLO, Data de Julgamento: 01/12/2005, Tribunal Pleno, Data de Publicação: DJe-177 Publicação em: 19-09-28. Disponível em $<$ http://redir.stf.jus.br/paginadorpub/pag inador.jsp?docTP=AC\&docID=548579>. Acesso em: 08 de março de 2015.
} 
Revista Eletrônica de Direito Processual - REDP. Volume 16. Julho a dezembro de 2015

Periódico Semestral da Pós-Graduação Stricto Sensu em Direito Processual da UERJ

Patrono: José Carlos Barbosa Moreira. ISSN 1982-7636. pp. 550-579 http://www.e-publicacoes.uerj.br/index.php/redp/index

concretização dos direitos e das liberdades de que são titulares as pessoas carentes e necessitadas. É por essa razão que a Defensoria Pública não pode (e não deve) ser tratada de modo inconsequente pelo Poder Público, pois a proteção jurisdicional de milhões de pessoas - carentes e desassistidas -, que sofrem inaceitável processo de exclusão jurídica e social, depende da adequada organização e da efetiva institucionalização desse órgão do Estado.

- De nada valerão os direitos e de nenhum significado revestir-se-ão as liberdades, se os fundamentos em que eles se apoiam - além de desrespeitados pelo Poder Público ou transgredidos por particulares - também deixarem de contar com o suporte e o apoio de um aparato institucional, como aquele proporcionado pela Defensoria Pública, cuja função precípua, por efeito de sua própria vocação constitucional (CF, art. 134), consiste em dar efetividade e expressão concreta, inclusive mediante acesso do lesado à jurisdição do Estado, a esses mesmos direitos, quando titularizados por pessoas necessitadas, que são as reais destinatárias tanto da norma inscrita no art. $5^{\circ}$, inciso LXXIV, quanto do preceito consubstanciado no art. 134, ambos da Constituição da República.

Trata-se de instituição essencial à garantia constitucional ao acesso à justiça pelos necessitados, que não possuem condição de arcar com as despesas de advogado sem prejuízo de sua subsistência. Nas palavras de Fredie Didier Jr. e Leonardo José Carneiro da Cunha ${ }^{3}$, Se o acesso à justiça constitui uma garantia fundamental $(\mathrm{CF} / 88$, art. $5^{\circ}, \mathrm{XXXV)}$, cumpre ao Estado prestar assistência jurídica integral e gratuita aos que comprovarem insuficiência de recursos (art. $5^{\circ}$, LXXIV).

Eis o contexto em que se insere a Defensoria Pública.

\footnotetext{
${ }^{3}$ DIDIER JR, Fredie; CUNHA, Leonardo José Carneiro da. Comentário ao artigo 134. In. CANOTILHO, J. J. Gomes; MENDES, Gilmar F.; SARLET, Ingo W.; STRECK, Lênio L. (Coords.). Comentários à Constituição do Brasil. São Paulo: Saraiva/Almedina, 2013, p. 1554.
} 
Revista Eletrônica de Direito Processual - REDP. Volume 16. Julho a dezembro de 2015

Periódico Semestral da Pós-Graduação Stricto Sensu em Direito Processual da UERJ

Patrono: José Carlos Barbosa Moreira. ISSN 1982-7636. pp. 550-579 http://www.e-publicacoes.uerj.br/index.php/redp/index

Os defensores públicos são, exatamente, os advogados públicos oferecidos pelo Estado a pessoas carentes.

A defensoria Pública é, então, instituição essencial à Justiça, com a mesma dignidade e importância que o Ministério Público, a Advocacia Pública e a Advocacia.

Seguindo tais vetores, a Lei Complementar nº 80/1994 (Lei Orgânica da Defensoria Pública), alterada profundamente pela Lei Complementar $n^{0} 132 / 2009$, traz a estruturação básica, garantias e prerrogativas institucionais, assim como direitos e deveres dos seus membros.

Entre os seus objetivos, elencados no art. $3^{\circ}$-A, da Lei Complementar $n^{\circ}$ 80/1994, encontram-se: a primazia da dignidade da pessoa humana e a redução das desigualdades sociais; a afirmação do Estado Democrático de Direito; a prevalência e efetividade dos direitos humanos; e a garantia dos princípios constitucionais da ampla defesa e do contraditório.

Desta forma, pode-se observar que o espectro de atuação da Defensoria Pública é bastante abrangente, eis que visa a garantir e promover os direitos das pessoas necessitadas. Trata-se de uma atuação que vai muito além de uma defesa processual, dentro do Poder Judiciário. Diz respeito à satisfação dos anseios dos necessitados da melhor forma possível a estes, em especial extrajudicialmente ${ }^{4}$ ou com medidas preventivas de violações de direitos.

Igualmente importante é o aspecto da defesa dos necessitados através de processos judiciais, seja nos casos de demandas que exigem a jurisdição, seja em casos cuja resolutividade extrajudicial não foi possível, diante da ausência de conciliação.

Ademais, além da amplitude de atuação da Defensoria Pública, quando se trata da defesa judicial, o Defensor Público, resguardada a sua independência funcional, não tem o condão de escolher os seus assistidos, pois todas as pessoas que são hipossuficientes (econômico ou jurídico), são assistidos em potencial. Não há escolha de quem assistir ou não. É dever constitucional a defesa de todos. Sobre tal assunto, inclusive, manifestou-se a

\footnotetext{
${ }^{4} \mathrm{O}$ NCPC inclusive estimula a prática conciliatória pela Defensoria Pública, conforme se verifica nos seus arts. $3^{\circ}, \S 3^{\circ}$ e 175 .
} 
Revista Eletrônica de Direito Processual - REDP. Volume 16. Julho a dezembro de 2015

Periódico Semestral da Pós-Graduação Stricto Sensu em Direito Processual da UERJ

Patrono: José Carlos Barbosa Moreira. ISSN 1982-7636. pp. 550-579 http://www.e-publicacoes.uerj.br/index.php/redp/index

comissão instituída pela Associação Nacional dos Defensores Públicos para análise do Projeto de Lei que resultou no novo CPC, verbis: ${ }^{5}$

Note-se que, ao contrário dos advogados privados e até mesmo das entidades que prestam assistência jurídica gratuita, os defensores públicos são pautados pelo princípio da indeclinabilidade das causas, isto é, não gozam da faculdade de negar o patrocínio dos interesses da população carente em razão de excesso de trabalho, falta de especialização quanto à matéria ou qualquer outro motivo.

Assim, o número de ações acompanhadas por um único defensor por vezes pode corresponder a até $70 \%$ das demandas em tramitação em um determinado juízo, sendo esta situação corriqueira em todo o país. Não é de se desprezar também que muitas Defensorias Públicas operam com severa redução de quadros, onde o acúmulo de causas é severo e a redação apresentada concorreria para inviabilizar a defesa efetiva de muitos carentes

Nesse ponto revela-se de extrema importância a previsão de dispositivos processuais específicos para a Defensoria Pública, de modo a garantir não apenas à instituição, mas aos próprios assistidos, que a defesa judicial seja realizada com o maior zelo e dedicação possíveis.

\section{A INSERÇÃO DA DEFENSORIA PÚBLICA NO CÓDIGO DE PROCESSO CIVIL DE 1973 E NO NOVO CÓDIGO DE PROCESSO CIVIL}

A redação original do Código de Processo Civil de 1973 não fez em seus dispositivos qualquer menção à Defensoria Pública. Tal fato se deu pelo simples fato de a instituição não ser prevista constitucionalmente à época. Observa-se que sequer na exposição de motivos do então Ministro da Justiça e principal mentor do CPC/73, Alfredo Buzaid, (Exposição de

\footnotetext{
${ }^{5}$ Associação Nacional dos Defensores Públicos (ANADEP). Parecer da comissão instituída pela Associação Nacional dos Defensores Públicos para Análise do Projeto do Novo Código de Processo Civil. Brasília, 2012. $\quad$ p. 17-18. Disponível em: $<$ http://www.anadep.org.br/wtksite/cms/conteudo/14949/Relat_rio_CPC_ANADE P_final_30_07.pdf> Acesso em: 08 de março de 2015.
} 
Revista Eletrônica de Direito Processual - REDP. Volume 16. Julho a dezembro de 2015

Periódico Semestral da Pós-Graduação Stricto Sensu em Direito Processual da UERJ

Patrono: José Carlos Barbosa Moreira. ISSN 1982-7636. pp. 550-579 http://www.e-publicacoes.uerj.br/index.php/redp/index

Motivos $n^{\circ}$ GM/473-B, de 31-7-72) ${ }^{6}$, houve qualquer previsão sobre a Defensoria Pública. Apenas com suas posteriores alterações, já na vigência da Constituição Republicana de 1988 é que, paulatinamente, a Defensoria Pública foi sendo inserida no codex.

Entre as alterações do Código de Processo Civil de 1973 encontram-se: 1) Lei no 8.953, de 13.12.1994, alterou o art. 585, II, possibilitando à Defensoria Pública referendar acordo extrajudicial, dando-lhe força de título extrajudicial ${ }^{7}$; 2) Lei $\mathrm{n}^{\circ} 11.965$, de 03.07.2009, possibilitou a participação do defensor público na lavratura da escritura pública de inventário e de partilha, de separação consensual e de divórcio consensual ${ }^{8}$; 3) Lei ${ }^{\circ} 11.382$, de 06.12.2006, que pró́be membros da Defensoria Pública de apresentar lances em praças ou leilões judiciais 9 .

Verifica-se, pois, que foram alterações pontuais que, apesar da extrema importância, não tiveram maiores reflexos na atuação judicial dos membros da Defensoria Pública, ou seja, dentro de uma demanda judicializada, eis que dispuseram, essencialmente, sobre a possibilidade de resolução extrajudicial, envolvendo direitos disponíveis, e casos de direito de família e sucessões em que não houver conflito.

Desta forma, a atuação e as garantias previstas aos membros da Defensoria Pública, durante a vigência do Código de Processo Civil de 1973, eram previstas exclusivamente na Lei Orgânica (Lei Complementar nº 80/1994), de modo que não havia, como dito alhures, um enraizamento da instituição dentro do processo judicializado.

\footnotetext{
${ }^{6}$ BRASIL. Código de processo civil: histórico da lei. Volume I. Tomo I. SENADO FEDERAL: 1974. Disponibilizado em: http://www2.senado.leg.br/bdsf/bitstream/handle/id/177828/CodProcCivil\%201974.pdf?sequence=4. Acesso em: 08 de março de 2015.

${ }^{7}$ Art. 585. São títulos executivos extrajudiciais:

$[\ldots]$

II - a escritura pública ou outro documento público assinado pelo devedor; o documento particular assinado pelo devedor e por duas testemunhas; o instrumento de transação referendado pelo Ministério Público, pela Defensoria Pública ou pelos advogados dos transatores;

${ }^{8}$ Art. 982. [...]

$\S 1^{\circ} \mathrm{O}$ tabelião somente lavrará a escritura pública se todas as partes interessadas estiverem assistidas por advogado comum ou advogados de cada uma delas ou por defensor público, cuja qualificação e assinatura constarão do ato notarial.

Art. 1.124-A. [...]

$\S 2^{\circ}$ O tabelião somente lavrará a escritura se os contratantes estiverem assistidos por advogado comum ou advogados de cada um deles ou por defensor público, cuja qualificação e assinatura constarão do ato notarial.

${ }^{9}$ Art. 690-A. É admitido a lançar todo aquele que estiver na livre administração de seus bens, com exceção: [...]

III - do juiz, membro do Ministério Público e da Defensoria Pública, escrivão e demais servidores e auxiliares da Justiça.
} 
Revista Eletrônica de Direito Processual - REDP. Volume 16. Julho a dezembro de 2015

Periódico Semestral da Pós-Graduação Stricto Sensu em Direito Processual da UERJ

Patrono: José Carlos Barbosa Moreira. ISSN 1982-7636. pp. 550-579 http://www.e-publicacoes.uerj.br/index.php/redp/index

Assim, o NCPC foi bastante feliz em dispor em título próprio acerca da Defensoria Pública (Título VII), dentro do Livro destinado aos sujeitos do processo (Livro III), especificando, na medida do possível, o seu papel dentro do processo civil. Desta forma, reitera-se o reconhecimento da importância da instituição dentro do procedimento judicializado.

Foi igualmente importante a codificação de dispositivos esparsos que, apesar de já previstos em outras leis ou mesmo em entendimentos jurisprudenciais, dá harmonia e sentido à forma de atuar do órgão defensorial. Entre os quais, a previsão expressa da Defensoria Pública como titular do exercício da curadoria especial, para garantia da defesa técnica dos indivíduos que não foram citados pessoalmente.

\section{A DEFENSORIA PÚBLICA COMO SUJEITO PROCESSUAL -} LEGITIMAÇÃO AUTÔNOMA PARA A CONDUÇÃO DO PROCESSO EM FAVOR DO ASSISTIDO

Um dos princípios institucionais da Defensoria Pública é a sua independência funcional, prevista no art. $134, \S 4^{\circ}$ da Constituição da República ${ }^{10}$. Tal independência funcional dá ao membro da Defensoria Pública a autonomia necessária para a condução dos interesses do seu assistido da melhor forma possível, livre de interferências externas.

Dissecando o assunto, doutrina Silvio Roberto Mello Moraes ${ }^{11}$ :

A independência funcional é princípio dos mais valiosos para a Instituição. Para que cumpra seu dever constitucional de manutenção do Estado Democrático de Direito, assegurando a igualdade substancial entre todos os cidadãos, bem como instrumentalizando o exercício de diversos direitos e garantias individuais, representando, junto aos Poderes constituídos, os hipossuficientes, não raras vezes contra o próprio Estado, é necessário que a Defensoria Pública guarde uma posição de independência e autonomia em relação aos

\footnotetext{
${ }^{10}$ Art. $134[\ldots]$

$[\ldots]$

$\S 4^{\circ}$ São princípios institucionais da Defensoria Pública a unidade, a indivisibilidade e a independência funcional, aplicando-se também, no que couber, o disposto no art. 93 e no inciso II do art. 96 desta Constituição Federal

${ }^{11}$ MORAES, Silvio Roberto Mello. Princípios institucionais da Defensoria Pública - Lei Complementar 80, de 12.1.1994 anotada. São Paulo: Revistas dos Tribunais, 1995, p. 22.
} 
Revista Eletrônica de Direito Processual - REDP. Volume 16. Julho a dezembro de 2015

Periódico Semestral da Pós-Graduação Stricto Sensu em Direito Processual da UERJ

Patrono: José Carlos Barbosa Moreira. ISSN 1982-7636. pp. 550-579 http://www.e-publicacoes.uerj.br/index.php/redp/index

demais organismos estatais e ao próprio Poder ao qual encontra-se, de certa forma, vinculada.

Baseando-se nesse panorama da Defensoria Pública como entidade dotada de independência na sua atuação, o NCPC, no Título VII do Livro III, previu-a como sujeito do processo. É, portanto, o maior reconhecimento feito pela lei civil adjetiva acerca da essencialidade da Defensoria Pública no atual cenário processual brasileiro, pois confere-lhe legitimação autônoma para atuar em processos envolvendo direitos individuais ou coletivos dos necessitados.

Prescreve o artigo 185 da Lei ${ }^{\circ} 13.105 / 2015$ :

Art. 185. A Defensoria Pública exercerá a orientação jurídica, a promoção dos direitos humanos e a defesa dos direitos individuais e coletivos dos necessitados, em todos os graus, de forma integral e gratuita.

Ao reconhecer a Defensoria Pública como sujeito processual incumbido da defesa dos direitos individuais e coletivos dos necessitados, dá-se a legitimação autônoma para tal instituição na condução do processo.

Nesse diapasão, e dispondo sobre a função institucional da Defensoria Pública, prevê o art. $4^{\circ}, \mathrm{X}$, da Lei Complementar 80/94, que a Defensoria Pública pode, para a garantia dos direitos individuais, sociais e promoção dos direitos fundamentais (direitos humanos positivados na ordem constitucional), ajuizar qualquer tipo de ação necessária para tanto. Verbis:

Art. $4^{\circ}$ São funções institucionais da Defensoria Pública, dentre outras:

$[\ldots]$

$\mathrm{X}$ - promover a mais ampla defesa dos direitos fundamentais dos necessitados, abrangendo seus direitos individuais, coletivos, sociais, econômicos, culturais e ambientais, sendo admissíveis todas as espécies de ações capazes de propiciar sua adequada e efetiva tutela 
Revista Eletrônica de Direito Processual - REDP. Volume 16. Julho a dezembro de 2015

Periódico Semestral da Pós-Graduação Stricto Sensu em Direito Processual da UERJ

Patrono: José Carlos Barbosa Moreira. ISSN 1982-7636. pp. 550-579 http://www.e-publicacoes.uerj.br/index.php/redp/index

Trata-se, neste ponto, conforme dito, da legitimação autônoma para a condução do processo, franqueada a algumas instituições (em especial a Defensoria Pública e o Ministério Público), consistente na possibilidade de ajuizar e acompanhar demandas independentemente de atuarem em nome de outrem, pois, em verdade, atuam em nome próprio. Aplica-se, aqui, o raciocínio expedido por Nelson Nery Júnior e Rosa Maria de Andrade $\mathrm{Nery}^{12}$ no que tange a processos coletivos:

A dicotomia clássica legitimação ordinária-extraordinária só tem cabimento para a explicação de fenômenos envolvendo direito individual. Quando a lei legitima alguma entidade a defender direito não individual (coletivo ou difuso), o legitimado não estará defendendo direito alheio em nome próprio, porque não se pode identificar o titular do direito. Não poderia ser admitida ação judicial proposta pelos 'prejudicados pela poluição', pelos ‘consumidores de energia elétrica', enquanto classe ou grupo de pessoas. A legitimidade para a defesa dos direitos difusos e coletivos em juízo não é extraordinária (substituição processual), mas sim legitimação autônoma para a condução do processo (selbständige Prozebführungsbefgnis): a lei elegeu alguém para a defesa de direitos porque seus titulares não podem individualmente fazê-lo.

Com a Lei $n^{o}$ 13.105/2015, há uma evolução no conceito de parte e de sujeito processual. Não há mais apenas a dualidade entre partes e juiz, porém uma abertura do leque de entes atuantes, para que o processo se resolva o mais brevemente possível. Tanto é assim que o art. $6^{\circ}$ da nova lei civil adjetiva dispõe que "todos os sujeitos do processo devem cooperar entre si para que se obtenha, em tempo razoável, decisão de mérito justa e efetiva".

Afirmam Humberto Theodoro Jr. et $a l^{13}$ que "tal opção legislativa mostra que mediante o novo texto não é mais possível cogitar em centralidade do juiz ou das partes; o Novo CPC é um código de todos os sujeitos processuais, é, portanto, policêntrico".

\footnotetext{
${ }^{12}$ NERY JR., Nelson; NERY, R. M. de A. Código de processo civil comentado. 5. ed. São Paulo: RT, 2001, p. 1866.

${ }^{13}$ BAHIA, Alexandre Melo Franco; NUNES, Dierle; PEDRON, Flávio Quinaud; THEODORO JR., Humberto. Novo CPC: fundamentos e sistematização. Rio de Janeiro: Forense, 2015, p. 78.
} 
Revista Eletrônica de Direito Processual - REDP. Volume 16. Julho a dezembro de 2015

Periódico Semestral da Pós-Graduação Stricto Sensu em Direito Processual da UERJ

Patrono: José Carlos Barbosa Moreira. ISSN 1982-7636. pp. 550-579 http://www.e-publicacoes.uerj.br/index.php/redp/index

Observa-se, desta forma, que a Defensoria Pública vai a juízo por si própria, prestando assistência integral e gratuita ao indivíduo, que é parte no processo. Tanto é assim, que a Defensoria Pública atua na defesa do assistido independentemente de mandato, conforme previsto nos artigos 44, XI, 89, XI e 128, XI, da Lei Complementar $n^{\circ} 80 / 1994^{14}$, e art. 287, parágrafo único, II, do Novo $\mathrm{CPC}^{15}$.

Ademais, o art. 720, NCPC, traz claramente a distinção entre interessado, Ministério Público e Defensoria Pública como sujeitos aptos à instauração de processos relativos à jurisdição voluntária, veja-se:

Art. 720. O procedimento terá início por provocação do interessado, do Ministério Público ou da Defensoria Pública, cabendo-lhes formular o pedido devidamente instruído com os documentos necessários e com a indicação da providência judicial.

Ressalte-se, entretanto, que essa legitimação autônoma, nas demandas individuais, permanece apenas enquanto houver a condição essencial de necessitado do indivíduo. Tal hipossuficiência deve ser encarada tanto no seu sentido jurídico quanto no seu sentido financeiro. Sabe-se que a hipossuficiência financeira, assim como a jurídica, pode (e deve) ser transitória, de modo que, uma vez findada a situação de hipossuficiência, carece de base para a atuação da Defensoria Pública, e assim, a partir daquele momento, ela não mais deverá fazer parte da relação processual, eis que desapareceu a base (condição de necessitado),

\footnotetext{
${ }^{14}$ Art. 44. São prerrogativas dos membros da Defensoria Pública da União:

[...]

XI - representar a parte, em feito administrativo ou judicial, independentemente de mandato, ressalvados os casos para os quais a lei exija poderes especiais;

Art. 89. São prerrogativas dos membros da Defensoria Pública do Distrito Federal e dos Territórios:

$[\ldots]$

XI - representar a parte, em feito administrativo ou judicial, independentemente de mandato, ressalvados os casos para os quais a lei exija poderes especiais;

Art. 128. São prerrogativas dos membros da Defensoria Pública do Estado, dentre outras que a lei local estabelecer:

$[\ldots]$

XI - representar a parte, em feito administrativo ou judicial, independentemente de mandato, ressalvados os casos para os quais a lei exija poderes especiais;

${ }^{15}$ Art. 287. A petição inicial deve vir acompanhada de procuração, que conterá os endereços do advogado, eletrônico e não eletrônico.

Parágrafo único. Dispensa-se a juntada da procuração:

[...]

II - se a parte estiver representada pela Defensoria Pública;
} 
Revista Eletrônica de Direito Processual - REDP. Volume 16. Julho a dezembro de 2015

Periódico Semestral da Pós-Graduação Stricto Sensu em Direito Processual da UERJ

Patrono: José Carlos Barbosa Moreira. ISSN 1982-7636. pp. 550-579 http://www.e-publicacoes.uerj.br/index.php/redp/index

devendo a parte constituir advogado ${ }^{16}$. Tal fato, por si só, não retira ou diminui a autonomia da Defensoria Pública como sujeito do processo, ao revés, reafirma que a Defensoria Pública apenas atua enquanto subsiste a condição de hipossuficiente, tendo autonomia para ingressar e deixar de prosseguir no processo.

Dessarte, não se pode mais perceber uma relação jurídico-processual como apenas uma relação triangular que espelha a relação jurídico-substantiva. Ao revés, com o novo Código de Processo Civil exsurge uma dinamicidade dos agentes processuais atuantes para a rápida solução do conflito.

Assim, levando em conta a nova normativa constitucional instituída pela Emenda Constitucional 80/2014, bem como a previsão do art. $4^{\circ}, \mathrm{X}$, da Lei Complementar $\mathrm{n}^{\mathrm{o}}$ 80/1994, outra conclusão não é possível senão a de que a Defensoria Pública possui legitimação autônoma para ajuizar qualquer tipo de ação necessária para a proteção dos direitos de seus assistidos, sejam de natureza individual ou coletiva.

\section{A DEFENSORIA PÚBLICA E A CURADORIA ESPECIAL}

De acordo com a doutrina de Frederico Rodrigues Viana de Lima ${ }^{17}$,

a curatela especial - também denominada curadoria à lide, para esclarecer que se cinge apenas ao processo - possui caráter eminentemente protetivo. Tem por escopo garantir concreta assistência jurídica aos beneficiários, uma vez que a peculiar condição que assumem pode impedi-los de terem ciência e de poderem se defender de forma eficaz.

O Código de Processo Civil de 1973, em seu artigo $9^{\circ}$, previu a figura da curadoria especial para a defesa do incapaz que não tivesse representante legal, ou se seus interesses

\footnotetext{
${ }^{16}$ Diversas leis estaduais dispõem sobre os critérios para se aferir a necessidade financeira apta para a assistência pela Defensoria Pública. A título exemplificativo, a Defensoria Pública do Estado do Maranhão prevê, na Lei Complementar Estadual no 19/1994, que é necessitado aquele cuja renda pessoal seja inferior a três salários mínimos, ou a média per capita de sua família não ultrapasse metade desse valor. Assim, supondo que um indivíduo queira ingressar com uma ação de usucapião de bem imóvel e comprove que sua renda seja apta à assistência gratuita prestada pela Defensoria, deverá a instituição ingressar autonomamente com tal demanda, prestando assistência integral e gratuita a este indivíduo, que é parte. Caso posteriormente não persista a situação de necessitado financeiro (indivíduo consiga um emprego com renda superior ao critério de necessitado para a Defensoria Pública), deverá a instituição não mais prestar assistência para este indivíduo, requerendo a sua exclusão da lide e solicitando a intimação pessoal da parte para que constitua advogado.

${ }^{17}$ LIMA, Frederico Rodrigues Viana de. Defensoria Pública. 3. ed. Salvador: Juspodivm, 2014, p.191.
} 
Revista Eletrônica de Direito Processual - REDP. Volume 16. Julho a dezembro de 2015

Periódico Semestral da Pós-Graduação Stricto Sensu em Direito Processual da UERJ

Patrono: José Carlos Barbosa Moreira. ISSN 1982-7636. pp. 550-579 http://www.e-publicacoes.uerj.br/index.php/redp/index

se colidissem com os do representante, para réu preso, bem como ao revel citado por edital ou com hora certa.

O NCPC, por seu turno, dispôs de forma similar, com algumas modificações pontuais e necessárias ${ }^{18}$, verbis:

Art. 72. O juiz nomeará curador especial ao:

I -incapaz, se não tiver representante legal ou se os interesses deste

colidirem com os daquele, enquanto durar a incapacidade;

II - réu preso revel, bem como ao réu revel citado por edital ou com hora certa, enquanto não for constituído advogado.

A finalidade da curadoria especial é, eminentemente, a garantia constitucional do contraditório e da ampla defesa, prevista no art. $5^{\circ}, \mathrm{LV}, \mathrm{CRFB} / 88^{19}$. Ela se bifurca em duas possibilidades: de indivíduos que, pela condição especial que se encontram, não têm como promover a defesa de seus interesses, e a de indivíduos que não foram citados pessoalmente, mas apenas de forma ficta. No primeiro caso, encontram-se os incapazes sem representantes legais e o réu preso. No segundo caso, verifica-se que, ainda que os indivíduos não saibam que contra eles corre determinada demanda, ainda assim lhes serão assegurados o contraditório e a ampla defesa. Em ambos os casos é clara a hipossuficiência dos indivíduos protegidos pela norma processual.

Desta forma, considerando que incumbe à Defensoria Pública a defesa dos interesses dos necessitados (hipossuficientes financeiros ou jurídicos), conforme amplamente abordado no presente artigo, a ela naturalmente é dada a função de proteção dos direitos de tais indivíduos. Tanto é assim, que o parágrafo único do art. 72 do Novo Código de Processo Civil previu que "a curatela especial será exercida pela Defensoria Pública, nos termos da lei".

Conforme indica a comissão da ANADEP:

a curadoria especial não intervém de maneira gratuita, ou por qualquer veleidade corporativa. A curadoria especial intervém

\footnotetext{
${ }^{18}$ Além da previsão do art. 72, verifica-se a curadoria especial nos procedimentos de inventário e partilha (art. 671), e de interdição (art. 752, §2 $2^{\circ}$.

${ }^{19}$ Art. $5^{\circ}[\ldots]$

LV - aos litigantes, em processo judicial ou administrativo, e aos acusados em geral são assegurados o contraditório e ampla defesa, com os meios e recursos a ela inerentes;
} 
Revista Eletrônica de Direito Processual - REDP. Volume 16. Julho a dezembro de 2015

Periódico Semestral da Pós-Graduação Stricto Sensu em Direito Processual da UERJ

Patrono: José Carlos Barbosa Moreira. ISSN 1982-7636. pp. 550-579 http://www.e-publicacoes.uerj.br/index.php/redp/index

porque há uma necessidade real. Não temos, longe disso, a hipótese de um órgão público batendo cabeça com outro. Na verdade, tratase de levar a sério, usando-se a conhecida expressão de Ronald Dworkin, a proteção integral garantida pela Constituição "cidadã". O propósito, insista-se, é de que a Constituição seja cumprida da maneira mais substancial possível, sobretudo quando estão em jogo as pessoas mais carentes que podem existir no Estado brasileiro crianças e adolescentes carentes e abandonados pela sorte. ${ }^{20}$

A curadoria especial a cargo da Defensoria Pública, no entanto, não é novidade legislativa, pois já existe desde a Lei Complementar no 80/1994, que em seu art. 4º, XVI, dispõe:

Art. $4^{\circ}$ São funções institucionais da Defensoria Pública, dentre outras:

$[\ldots]$

XVI - exercer a curadoria especial nos casos previstos em lei

Ademais, em que pese ausência de dispositivo legal expresso, tal garantia de curadoria especial é garantida em todo e qualquer procedimento que possa vir a restringir direitos e que seja necessária a conclusão da relação processual com a citação. Desta forma, continua válida a Súmula no 196 do Superior Tribunal de Justiça, a qual dispõe que "ao executado que, citado por edital ou por hora certa, permanecer revel, será nomeado curador especial, com legitimidade para apresentação de embargos".

Ressalte-se que, por ser função legalmente atribuída à Defensoria Pública diante da hipossuficiência jurídica desses indivíduos, a ela não se faz possível o pagamento de honorários pelo beneficiário da curadoria especial, à exceção de honorários sucumbenciais, caso encerre vencedora ${ }^{21}$.

\footnotetext{
20 Associação Nacional dos Defensores Públicos (ANADEP). Parecer da comissão instituída pela Associação Nacional dos Defensores Públicos para Análise do Projeto do Novo Código de Processo Civil. Brasília, 2012. $\quad$ p. $06 . \quad$ Disponível em: $<$ http://www.anadep.org.br/wtksite/cms/conteudo/14949/Relat_rio_CPC_ANADE P_final_30_07.pdf > Acesso em: 08 de março de 2015.

${ }^{21}$ Nesse sentido é o entendimento do Superior Tribunal de Justiça, verbis:
} 
Revista Eletrônica de Direito Processual - REDP. Volume 16. Julho a dezembro de 2015

Periódico Semestral da Pós-Graduação Stricto Sensu em Direito Processual da UERJ

Patrono: José Carlos Barbosa Moreira. ISSN 1982-7636. pp. 550-579 http://www.e-publicacoes.uerj.br/index.php/redp/index

Por fim, encontra-se expressamente excluída a aplicação do ônus da impugnação especificada ao réu quando sua defesa é formulada pela Defensoria Pública na qualidade de curadora especial. É o que diz o art. 341, parágrafo único, veja-se:

Art. 341. Incumbe também ao réu manifestar-se precisamente sobre as alegações de fato constantes da petição inicial, presumindose verdadeiras as não impugnadas, salvo se:

\section{$[\ldots]$}

Parágrafo único. O ônus da impugnação especificada dos fatos não se aplica ao defensor público, ao advogado dativo e ao curador especial.

Dúvida há, diante da novidade legislativa, se tal ônus da impugnação especificada dos fatos não se aplica ao defensor público de forma indiscriminada ou apenas quando estiver exercendo o múnus da curadoria especial. É que o dispositivo tem redação que pode vir a gerar divergência quando de sua aplicação.

Nesse espeque, defendemos a interpretação literal e sistematizada do citado dispositivo, eis que, caso quisesse que tal medida apenas se aplicasse à Defensoria Pública quando do exercício da curadoria especial, não haveria necessidade de distinção. Ademais, conforme já visto, é a Defensoria Pública quem possui a atribuição legal de exercer a curadoria especial (art. 72, p. ún., NCPC), de modo que não haveria qualquer necessidade

PROCESSO CIVIL. RECURSO ESPECIAL. CURADORIA ESPECIAL EXERCIDA PELADEFENSORIA PÚBLICA. DESEMPENHO DE FUNÇÃO INSTITUCIONAL. HONORÁRIOSNÃO DEVIDOS. DIFERENCIAÇÃO DOS HONORÁRIOS DE SUCUMBÊNCIA. DIREITO DADEFENSORIA PÚBLICA SALVO NA HIPÓTESE EM QUE PARTE INTEGRANTE DAPESSOA JURÍDICA DE DIREITO PÚBLICO, CONTRA A QUAL ATUA. SÚMULA 421DO STJ.

1. A Constituição da República, em seu art. 134, com vistas à efetividade do direito de defesa, determinou a criação da Defensoria Pública como instituição essencial à Justiça, tendo-lhe sido atribuída a curadoria especial como uma de suas funções institucionais (art. $4^{\circ}$, XVI, da LC 80/1994).

2. A remuneração dos membros integrantes da Defensoria Pública ocorre mediante subsídio em parcela única mensal, com expressa vedação a qualquer outra espécie remuneratória, nos termos dos arts. 135 e 39 , $\S 4^{\circ}$ da CF/88 combinado com o art. 130 da LC 80/1994.

3. Destarte, o defensor público não faz jus ao recebimento de honorários pelo exercício da curatela especial, por estar no exercício das suas funções institucionais, para o que já é remunerado mediante o subsídio em parcela única.

4. Todavia, caberá à Defensoria Pública, se for o caso, os honorários sucumbenciais fixados ao final da demanda (art. 20 do CPC), ressalvada a hipótese em que ela venha a atuar contra pessoa jurídica de direito público, à qual pertença (Súmula 421 do STJ).5. Recurso especial não provido.

(STJ Resp. $n^{\circ}$ 1.201.674 - SP, Relator: Ministro LUIS FELIPE SALOMÃO, Data de Julgamento: 06/06/2012, CE - CORTE ESPECIAL) 
Revista Eletrônica de Direito Processual - REDP. Volume 16. Julho a dezembro de 2015

Periódico Semestral da Pós-Graduação Stricto Sensu em Direito Processual da UERJ

Patrono: José Carlos Barbosa Moreira. ISSN 1982-7636. pp. 550-579 http://www.e-publicacoes.uerj.br/index.php/redp/index

na separação da curadoria especial e do defensor público no art. 341, parágrafo único, do Novo Código de Processo Civil.

Portanto, verifica-se que o ônus da impugnação especificada, em verdade, não se aplica a Defensoria Pública, seja na curadoria especial, seja na defesa dos interesses individuais dos hipossuficientes financeiros.

\section{DAS PRERROGATIVAS DOS DEFENSORES PÚBLICOS NO NCPC}

Os Defensores Públicos, como sujeitos do processo, estão submetidos aos regramentos legalmente previstos para a sua atuação, eis que o andamento procedimental, apesar de ter suas bases na Constituição, tem limitações impostas para garantir o bom andar dos feitos sujeitos ao Poder Judiciário. Contudo, conforme dito alhures, a Defensoria Pública é o órgão legitimamente investido na incumbência da defesa dos necessitados. Assim, o leque de assistidos pela Defensoria é enorme, eis que não pode escolher em que casos atuar.

Desta forma, para que seja realizado um serviço de qualidade, garantindo-se a eficiência do serviço público prestado, necessária a concessão de algumas prerrogativas à instituição quando de sua atuação. É com base nesse raciocínio que à Defensoria Pública é dado prazo em dobro em todas as suas manifestações, é necessária a intimação pessoal com vista dos autos para os seus membros, assim como é possível a intimação pessoal dos assistidos para providenciarem medidas necessárias ao andamento do processo e de testemunhas para comparecimento em audiência.

\subsection{Do prazo em dobro para manifestação no processo}

No Código de Processo Civil de 1973 não havia previsão de prazo diferenciado para a Defensoria Pública, apenas para a Fazenda Pública, Ministério Público ${ }^{22}$ e para litisconsortes com procuradores distintos ${ }^{23}$. O prazo diferenciado para a Defensoria Pública encontra guarida, desde 1994, em sua Lei Orgânica (Lei Complementar nº 80/1994), a qual prevê que em todas as manifestações da Defensoria Pública esta possuirá prazo em dobro para tanto ${ }^{24}$.

\footnotetext{
${ }^{22}$ Art. 188 Computar-se-á em quádruplo o prazo para contestar e em dobro para recorrer quando a parte for a Fazenda Pública ou o Ministério Público.

${ }^{23}$ Art. 191 Quando os litisconsortes tiverem diferentes procuradores, ser-lhes-ão contados em dobro os prazos para contestar, para recorrer e, de modo geral, para falar nos autos.

${ }^{24}$ Art. 44. São prerrogativas dos membros da Defensoria Pública da União:
} 
Revista Eletrônica de Direito Processual - REDP. Volume 16. Julho a dezembro de 2015

Periódico Semestral da Pós-Graduação Stricto Sensu em Direito Processual da UERJ

Patrono: José Carlos Barbosa Moreira. ISSN 1982-7636. pp. 550-579 http://www.e-publicacoes.uerj.br/index.php/redp/index

O NCPC uniformizou a concessão distinta de prazos, tanto para advogados públicos,

Ministério Público, Defensoria Pública, quanto para litisconsortes com advogados distintos. É o que se verifica dos arts. 180, 183, 186 e 229 da Lei no $13.105 / 2015^{25}$.

Ressalte-se que o prazo em dobro para os sujeitos processuais acima indicados é concedido de modo geral, sendo aplicado em todos os graus de jurisdição, relativamente à matéria cível, não prevalecendo quando há determinação de prazo específico para a instituição previsto em lei.

Portanto, não há mais distinção de prazos entre as instituições, ou mesmo em casos de advogados particulares de litisconsortes (com a ressalva de pertencerem ao mesmo escritório de advocacia), fator esse que as coloca em igual patamar.

Tal concessão de prazo independe de qualquer requerimento, eis que se trata de norma cogente, gerando o dever a sua observância, conforme já reconhecido pela jurisprudência pátria $^{26}$.

Sobre esse ponto argumenta Frederico Lima ${ }^{27}$ :

As prerrogativas surgem em razão da lei. Identificando-se que a representação da parte se dá pela Defensoria Pública,

I - receber, inclusive quando necessário, mediante entrega dos autos com vista, intimação pessoal em qualquer processo e grau de jurisdição ou instância administrativa, contando-se-lhes em dobro todos os prazos Art. 89. São prerrogativas dos membros da Defensoria Pública do Distrito Federal e dos Territórios:

I - receber, inclusive quando necessário, mediante entrega dos autos com vista, intimação pessoal em qualquer processo e grau de jurisdição ou instância administrativa, contando-se-lhes em dobro todos os prazos;

Art. 128. São prerrogativas dos membros da Defensoria Pública do Estado, dentre outras que a lei local estabelecer:

I - receber, inclusive quando necessário, mediante entrega dos autos com vista, intimação pessoal em qualquer processo e grau de jurisdição ou instância administrativa, contando-se-lhes em dobro todos os prazos;

${ }^{25}$ Art. 180. O Ministério Público gozará de prazo em dobro para manifestar-se nos autos, que terá início a partir de sua intimação pessoal, nos termos do art. $183, \S 10$.

Art. 183. A União, os Estados, o Distrito Federal, os Municípios e suas respectivas autarquias e fundações de direito público gozarão de prazo em dobro para todas as suas manifestações processuais, cuja contagem terá início a partir da intimação pessoal.

Art. 186. A Defensoria Pública gozará de prazo em dobro para todas as suas manifestações processuais.

Art. 229. Os litisconsortes que tiverem diferentes procuradores, de escritórios de advocacia distintos, terão prazos contados em dobro para todas as suas manifestações, em qualquer juízo ou tribunal, independentemente de requerimento.

26 AGRAVO REGIMENTAL NO AGRAVO EM RECURSO ESPECIAL. PROCESSUAL CIVIL. EMBARGOS À EXECUÇÃO. DEFENSORIA PÚBLICA. PRAZO EM DOBRO. ART. 44, I DA LC 80/94. AGRAVO DO MUNICÍPIO DE BELO HORIZONTE/MG DESPROVIDO.

1. O prazo para o ajuizamento de Embargos à Execução deve ser contado em dobro no caso em que a parte é representada pela Defensoria Pública, consoante disposição do art. 44, I da LC 80/94.

2. Agravo regimental do Município de Belo Horizonte/MG a que se nega provimento.

(STJ - AgRg no AREsp: 141859 MG 2012/0020215-1, Relator: Ministro NAPOLEÃO NUNES MAIA FILHO, Data de Julgamento: 02/09/2014, T1 - PRIMEIRA TURMA, Data de Publicação: DJe 17/09/2014)

${ }^{27}$ LIMA, Frederico Rodrigues Viana de. Defensoria Pública. 3. ed. Salvador: Juspodivm, 2014, p.307. 
Revista Eletrônica de Direito Processual - REDP. Volume 16. Julho a dezembro de 2015

Periódico Semestral da Pós-Graduação Stricto Sensu em Direito Processual da UERJ

Patrono: José Carlos Barbosa Moreira. ISSN 1982-7636. pp. 550-579 http://www.e-publicacoes.uerj.br/index.php/redp/index

automaticamente se aplica o mandamento legal que assegura a intimação pessoal e o prazo em dobro.

É desnecessário que o Poder Judiciário ou a autoridade administrativa as defira para que elas passem a existir no processo, pois elas não ocorrem ope judicis, mas, sim, ope legis. A partir do momento em que a Defensoria Pública oficia no feito - seja desde o início, seja em instante posterior -, os prazos devem ser duplicados e as intimações devem ser pessoais.

Insta asseverar que tal prerrogativa se estende aos escritórios de prática jurídica das faculdades de Direito e às entidades que prestam assistência jurídica gratuita, quando firmam convênios com a Defensoria Pública, ao teor do art. $186, \S^{\circ}, \mathrm{NCPC}^{28}$.

Alteração importante também se deu relativamente à contagem do prazo processual. No Código de Processo Civil de 1973 a contagem se dava em dias seguidos e ininterruptos ${ }^{29}$. Desta forma, iniciado o prazo, dias não úteis (sábados, domingos e feriados), eram computados na contagem do prazo processual.

Com o NCPC, a contagem do prazo se dá em dias úteis, conforme previsão no seu art. $219^{30}$. A consequência de tal mudança é o elastecimento dos prazos, dando-se, desta forma, maior lapso temporal para as manifestações.

\subsection{Da intimação pessoal do Defensor Público com vista dos autos}

Intimações, conforme lição de Cândido Rangel Dinamarco ${ }^{31}$, são "atos destinados a levar fatos ao conhecimento das partes ou terceiros, com eventual comando agregado, têm

\footnotetext{
${ }^{28}$ Art. $186[\ldots]$

$[\ldots]$

$\S 30$ O disposto no caput aplica-se aos escritórios de prática jurídica das faculdades de Direito reconhecidas na forma da lei e às entidades que prestam assistência jurídica gratuita em razão de convênios firmados com a Defensoria Pública.

${ }^{29}$ Art. 178. O prazo, estabelecido pela lei ou pelo juiz, é contínuo, não se interrompendo nos feriados.

${ }^{30}$ Art. 219. Na contagem de prazo em dias, estabelecido por lei ou pelo juiz, computar-se-ão somente os dias úteis.

31 DINAMARCO, Cândido Rangel. Instituições de Direito Processual Civil. V. III. 4. ed. São Paulo: Malheiros, 2004, p. 429.
} 
Revista Eletrônica de Direito Processual - REDP. Volume 16. Julho a dezembro de 2015

Periódico Semestral da Pós-Graduação Stricto Sensu em Direito Processual da UERJ

Patrono: José Carlos Barbosa Moreira. ISSN 1982-7636. pp. 550-579 http://www.e-publicacoes.uerj.br/index.php/redp/index

lugar ao longo de todo o procedimento e são indispensáveis sempre que do ato a ser conhecido o sujeito não tiver conhecimento direto".

Como atos que levam ao conhecimento dos sujeitos processuais determinadas decisões ou comandos, as intimações ocorrem ou por publicação na imprensa oficial ou pessoalmente. Via de regra, as intimações judiciais ocorrem pela imprensa oficial, através de publicações em diários eletrônicos dos próprios Tribunais. Contudo, em alguns casos específicos e excepcionais, as intimações ocorrem pessoalmente via mandado cumprido por Oficial de Justiça.

No caso das intimações dos Defensores Públicos, além de a intimação ser pessoal, esta deve se realizar com a entrega dos autos do processo em vista. Longe de ser regalia para os membros da instituição, essa intimação pessoal com vista dos autos é necessária eis que aplica em concreto a garantia do amplo acesso à justiça e ao contraditório, na medida em que fornece ao Defensor Público a possibilidade de bem examinar o processo e formular e melhor pretensão em favor do seu assistido.

O anterior Código de Processo Civil não continha qualquer dispositivo nesse sentido, sendo que a previsão legal aplicada sempre foi a contida nos arts. 44, I, 89, I e 128, I, da Lei Complementar $\mathrm{n}^{\circ}$ 80/1994.

Com o NCPC, há previsão expressa da intimação pessoal, conforme se verifica no art. $186, \S 1^{\circ}$, que dispõe: “O prazo tem início com a intimação pessoal do defensor público, nos termos do art. $183, \S 1^{\circ}$ ”.

Em que pese a ausência de previsão na Lei n ${ }^{\circ}$ 13.105/2015 acerca da entrega dos autos em vista, continua sendo necessária essa providência por aplicação dos já indicados artigos da Lei Complementar no 80/1994.

Ressalte-se que tal providência se faz necessária sob pena de nulidade dos atos realizados sem essa intimação com entrega dos autos em vista, independentemente do procedimento utilizado, veja-se:

PROCESSO CIVIL. RECURSO ESPECIAL. PROCEDIMENTO SUMÁRIO. DEFENSORIA PÚBLICA DO DISTRITO FEDERAL. PEDIDO DE VISTA E INTIMAÇÃO PESSOAL. PRERROGATIVAS DO DEFENSOR PÚBLICO. ART. 89 DA LC n. 80/1994. NEGATIVA DO JUÍZO. VIOLAÇÃO AO CONTRADITÓRIO E AMPLA DEFESA. DECRETAÇÃO DA 
Revista Eletrônica de Direito Processual - REDP. Volume 16. Julho a dezembro de 2015

Periódico Semestral da Pós-Graduação Stricto Sensu em Direito Processual da UERJ

Patrono: José Carlos Barbosa Moreira. ISSN 1982-7636. pp. 550-579 http://www.e-publicacoes.uerj.br/index.php/redp/index

REVELIA NA AUDIÊNCIA DE CONCILIAÇÃO.

IMPOSSIBLIDADE. 1. Firme no propósito de concentrar os atos processuais, o procedimento sumário prevê a necessidade de presença do réu na audiência de conciliação para que, primeiro, seja tentada a autocomposição da demanda e, em caso de negativa, se prossiga com a apresentação de contestação, sob pena de decretação da revelia.

2. Na hipótese, o pedido de vista dos autos pela Defensoria Pública, antes da audiência inicial, nada mais foi do que tentar garantir - em sua plenitude - a assistência à recorrente, conferindo-lhe, dentro da paridade de armas, a maior possibilidade de contrabalançar a desigualdade que afeta às partes, permitindo que ambos os litigantes tenham no processo as mesmas oportunidades de tentar influir na decisão da causa. A Defensoria Pública é instituição estatal criada com o escopo de prestar assistência jurídica integral e gratuita aos que comprovem a insuficiência de recursos, de função ímpar em nosso sistema e consagrada no art. 134 da Carta da Republica.

3. Nessa linha, ciente das consequências jurídicas da audiência inicial do rito sumário, bem como da supressão de seu direito de defesa pelo Juízo - a Defensoria Pública foi impedida de apreciar as circunstâncias da demanda -, não se poderia exigir conduta diversa da recorrente, estando justificada sua ausência, haja vista que, sem realmente poder efetivar a defesa técnica, violado estaria o contraditório, a ampla defesa e inevitavelmente seria tida como revel.

4. Recurso especial provido.

(STJ - REsp: 1096396 DF 2008/0218578-9, Relator: Ministro LUIS FELIPE SALOMÃO, Data de Julgamento: 07/05/2013, T4 QUARTA TURMA, Data de Publicação: DJe 21/05/2013)

Com efeito, a jurisprudência dos tribunais superiores (STF e STJ), é no sentido de que a intimação pessoal se perfectibiliza com o recebimento dos autos na Defensoria Pública, 
Revista Eletrônica de Direito Processual - REDP. Volume 16. Julho a dezembro de 2015

Periódico Semestral da Pós-Graduação Stricto Sensu em Direito Processual da UERJ

Patrono: José Carlos Barbosa Moreira. ISSN 1982-7636. pp. 550-579 http://www.e-publicacoes.uerj.br/index.php/redp/index

sendo desnecessário o ciente do membro da instituição nos autos. É que se presume que a intimação pessoal com recebimento dos autos em vista ocorre com a remessa dos autos ao prédio da Defensoria Pública, com o recebimento de funcionários responsáveis pela organização administrativa interna ${ }^{32}$.

Igualmente, a citação, notificação ou intimação se dá pessoalmente e com vista dos autos quando o Defensor Público exara seu ciente ou retira os autos no próprio cartório (ou secretaria) judicial. Tal ciência decorre de questão lógica, eis que está sendo disponibilizado ao membro da Defensoria o inteiro teor dos autos, de modo que, para fins de celeridade processual, se torna despicienda a remessa posterior ao órgão defensorial. Veja-se o art. 272, $\S 6^{\circ}$, do NCPC:

Art. 272. Quando não realizadas por meio eletrônico, consideramse feitas as intimações pela publicação dos atos no órgão oficial.

$[\ldots]$

$\S 60$ A retirada dos autos do cartório ou da secretaria em carga pelo advogado, por pessoa credenciada a pedido do advogado ou da sociedade de advogados, pela Advocacia Pública, pela Defensoria Pública ou pelo Ministério Público implicará intimação de qualquer decisão contida no processo retirado, ainda que pendente de publicação.

Portanto, uma vez exarado o ciente ou retirados os autos em cartório judicial, desde logo é considerada válida a intimação pessoal e com vistas dos autos ao Defensor Público, decorrendo a partir daí todos os consectários legais.

\footnotetext{
${ }^{32}$ Nesse sentido encontra-se o seguinte julgado:

Intimação pessoal do Defensor Público. Ofício encaminhado ao Defensor Público-Geral e recebido por servidor do órgão. Intimação pessoal configurada. (...) Configura-se razoável, para fins de intimação pessoal, proceder-se à inequívoca ciência da Defensoria Pública, por intermédio de ofício ou mandado, devidamente recebido, competindo à Instituição organizar a atuação de seus membros, sob pena de burocratizar o processo, em total desrespeito à efetividade e celeridade da Justiça. Aplica-se, por analogia, o entendimento desta Corte segundo o qual a entrega de processo em setor administrativo, formalizada a carga por servidor do órgão, configura intimação pessoal. Havendo intimação pessoal da Defensoria Pública estadual para a sessão de julgamento da apelação criminal, não há que se falar em nulidade no acórdão prolatado.

(HC 99.540, Rel. Min. Ellen Gracie, julgamento em 4-5-2010, Segunda Turma, DJE de 21-5-2010.) Vide: AP 458 petição avulsa-AgR, Rel. Min. Joaquim Barbosa, julgamento em 12-3-2009, Plenário, DJE de 29-10-2009; AI 707.988-AgR, Rel. Min. Cármen Lúcia, julgamento em 12-8-2008, Primeira Turma, DJE de 19-9-2008; HC 83.255, Rel. Min. Marco Aurélio, julgamento em 5-11-2003, Plenário, DJ de 12-3-2004.
} 
Revista Eletrônica de Direito Processual - REDP. Volume 16. Julho a dezembro de 2015

Periódico Semestral da Pós-Graduação Stricto Sensu em Direito Processual da UERJ

Patrono: José Carlos Barbosa Moreira. ISSN 1982-7636. pp. 550-579 http://www.e-publicacoes.uerj.br/index.php/redp/index

Questão tormentosa existe quando se trata de processos eletrônicos. Hodiernamente há convergência de que se virtualizem os processos judiciais, de modo a efetivar celeridade processual e facilitar o acesso tanto pelos sujeitos processuais quanto pelo jurisdicionado, pois multiplica a possibilidade de visualização e informação, em qualquer horário ou local, independentemente de requerimento.

A Lei $n^{0} 11.419 / 06$, que regulamentou a informatização do processo judicial, dispõe no art. $9^{\circ}$ que as citações notificações e intimações em processos eletrônicos que viabilizem o acesso à íntegra do processo respectivo serão consideradas vista pessoal, devendo apenas em caso de impossibilidade se utilizar os meios ordinários de intimação (intimação via mandado). Observe-se:

Art. $9^{\circ}$ No processo eletrônico, todas as citações, intimações e notificações, inclusive da Fazenda Pública, serão feitas por meio eletrônico, na forma desta Lei.

$\S 1^{\circ}$ As citações, intimações, notificações e remessas que viabilizem o acesso à íntegra do processo correspondente serão consideradas vista pessoal do interessado para todos os efeitos legais.

$\S 2^{\circ}$ Quando, por motivo técnico, for inviável o uso do meio eletrônico para a realização de citação, intimação ou notificação, esses atos processuais poderão ser praticados segundo as regras ordinárias, digitalizando-se o documento físico, que deverá ser posteriormente destruído.

Considerando ser tendência inevitável a informatização do processo judicial, o NCPC determina o cadastramento da Defensoria Pública nos sistemas eletrônicos que paulatinamente estão sendo disponibilizados pelo Poder Judiciário, para que passem a receber citações, notificações e intimações eletronicamente. Essa previsão está contida no art. 270 , p. ún., c/c art. $246, \S 1^{\circ}$, verbis:

Art. 270. As intimações realizam-se, sempre que possível, por meio eletrônico, na forma da lei.

Parágrafo único. Aplica-se ao Ministério Público, à Defensoria Pública e à Advocacia Pública o disposto no $§ 10$ do art. 246. 
Revista Eletrônica de Direito Processual - REDP. Volume 16. Julho a dezembro de 2015

Periódico Semestral da Pós-Graduação Stricto Sensu em Direito Processual da UERJ

Patrono: José Carlos Barbosa Moreira. ISSN 1982-7636. pp. 550-579 http://www.e-publicacoes.uerj.br/index.php/redp/index

Art. 246. A citação será feita:

$[\ldots]$

$\S 10$ Com exceção das microempresas e das empresas de pequeno porte, as empresas públicas e privadas são obrigadas a manter cadastro nos sistemas de processo em autos eletrônicos, para efeito de recebimento de citações e intimações, as quais serão efetuadas preferencialmente por esse meio.

Deste modo, a exigência supra é legítima e válida como pessoal apenas em se tratando de processos eletrônicos que tramitam integralmente em sistemas informatizados, cujo conteúdo integral dos autos seja disponibilizado ao membro da Defensoria Pública.

Portanto, verifica-se que a intimação pessoal dos membros da Defensoria Pública deve ocorrer mediante a entrega dos autos em vista, ressalvando-se a possibilidade de intimação eletrônica em processos que tramitam na forma informatizada, tudo para garantir a defesa dos assistidos em sua plenitude.

\subsection{Da possibilidade de intimação pessoal dos assistidos para providências} processuais e das testemunhas para comparecerem em audiência

No dia-a-dia da atividade da Defensoria Pública há o atendimento de diversas pessoas, as quais, pela condição de necessitados, muitas vezes não possuem telefones ou outros meios para contato pessoal direto, fato esse que dificulta a colheita de informações no decorrer do processo judicial, como por exemplo, novo endereço para citação do réu, ou determinação para apresentação de um determinado documento, etc.

Com efeito, a Defensoria Pública, por ser uma instituição nova e em desenvolvimento, possui em regra pequeno corpo funcional, não dispondo de pessoal suficiente para sempre ir às casas dos assistidos para colher informações necessárias para o regular andamento do processo. Desta forma busca-se sempre o contato telefônico que, muitas vezes, não consegue o objetivo do contato pessoal.

Assim, o NCPC, para alcançar a finalidade da tutela jurisdicional efetiva, considerando a condição de necessitado das pessoas que são assistidas pela Defensoria Pública, e baseado na cooperação entre as instituições (art. $6^{\circ}, \mathrm{NCPC}$ ), determina que o Poder Judiciário preste 
Revista Eletrônica de Direito Processual - REDP. Volume 16. Julho a dezembro de 2015

Periódico Semestral da Pós-Graduação Stricto Sensu em Direito Processual da UERJ

Patrono: José Carlos Barbosa Moreira. ISSN 1982-7636. pp. 550-579 http://www.e-publicacoes.uerj.br/index.php/redp/index

auxílio nesse ponto, através de seu corpo institucional, mormente pelo profícuo trabalho dos oficiais de justiça, para que possa haver o contato direto com a parte, com o fito de manifestar-se ou providenciar o necessário ao andamento do feito.

Desta forma é que o NCPC, em seu artigo $186, \S 2^{\circ}$, dispõe sobre tal possibilidade de o juiz determinar a intimação pessoal da parte assistida pela Defensoria Pública para providência ou informação necessária, veja-se:

Art. 186. A Defensoria Pública gozará de prazo em dobro para todas as suas manifestações processuais.

$[\ldots]$

$\S 2^{\circ}$ A requerimento da Defensoria Pública, o juiz determinará a intimação pessoal da parte patrocinada quando o ato processual depender de providência ou informação que somente por ela possa ser realizada ou prestada.

Tal previsão já havia receptividade por parte de alguns Tribunais, conforme se verifica no seguinte julgado:

PROCESSUAL CIVIL. DOCUMENTO ESSENCIAL À PROPOSITURA DA AÇÃO. INTIMAÇÃO PESSOAL DE PARTE ASSISTIDA PELA DEFENSORIA PÚBLICA. NECESSIDADE. EXTINÇÃO DO FEITO SEM EXAME DO MÉRITO. DESCABIMENTO.

Tratando-se de parte assistida pela Defensoria Pública, a intimação para a emenda da inicial, visando o cumprimento de exigência só realizável pelo próprio Autor, deve ser procedida na pessoa desta, e não ao Defensor que exerce o patrocínio da causa.

Notório o fato de que a Defensoria Pública não goza da mesma disponibilidade dos advogados particulares, atuando, na maioria das vezes, sem muita proximidade de seus assistidos.

Logo, no presente caso, a determinação de juntada de documento essencial à propositura da ação cumpre ser feita ao próprio Autor que, em última análise, é que sofrerá as consequências pelo indeferimento da inicial. 
Revista Eletrônica de Direito Processual - REDP. Volume 16. Julho a dezembro de 2015

Periódico Semestral da Pós-Graduação Stricto Sensu em Direito Processual da UERJ

Patrono: José Carlos Barbosa Moreira. ISSN 1982-7636. pp. 550-579 http://www.e-publicacoes.uerj.br/index.php/redp/index

Sentença cassada. Apelação provida.

(TRF-2 - AC: 160100 98.02.01927-5, Relator:

Desembargador Federal SERGIO FELTRIN CORREA, Data de Julgamento: 20/06/2001, SEGUNDA TURMA, Data de Publicação: DJU - Data::06/11/2001).

Outrossim, prevê a Lei $n^{\circ} 13.105 / 2015$, no art. $455, \S 4^{\circ}$, IV ${ }^{33}$, que as testemunhas arroladas pela Defensoria Pública devem ser intimadas pela via judicial, enquanto a regra geral (caput desse mesmo artigo) é que os advogados providenciem a comunicação das testemunhas acerca da data, horário e local da realização da audiência.

Portanto, tal previsão veio para facilitar o acesso à justiça aos necessitados, assim como preservar o princípio constitucional do contraditório, dando a possibilidade de a Defensoria Pública efetuar serviço seu serviço de forma célere e eficaz, o que, ao final, beneficia sempre o hipossuficiente.

\section{DEVERES E RESPONSABILIDADES DO DEFENSOR PÚBLICO NO}

\section{NCPC:}

Os membros da Defensoria Pública possuem, além de prerrogativas, deveres legais impostos ao exercício de suas funções que, entre as quais as previstas no art. 116, incisos I, II, III, IX e XI da Lei $n^{\circ} 8112 / 90^{34}$, previstas para os servidores públicos em geral, mas que são igualmente aplicáveis aos Defensores Públicos.

\footnotetext{
${ }^{33}$ Art. 455. Cabe ao advogado da parte informar ou intimar a testemunha por ele arrolada do dia, da hora e do local da audiência designada, dispensando-se a intimação do juízo.

[...]

$\S 4$ o A intimação será feita pela via judicial quando:

$[\ldots]$

IV - a testemunha houver sido arrolada pelo Ministério Público ou pela Defensoria Pública;

${ }^{34}$ Art. 116. São deveres do servidor:

I - exercer com zelo e dedicação as atribuições do cargo;

II - ser leal às instituições a que servir;

III - observar as normas legais e regulamentares;

[...]

IX - manter conduta compatível com a moralidade administrativa;

$[\ldots]$

XI - tratar com urbanidade as pessoas;

XII - representar contra ilegalidade, omissão ou abuso de poder.
} 
Revista Eletrônica de Direito Processual - REDP. Volume 16. Julho a dezembro de 2015

Periódico Semestral da Pós-Graduação Stricto Sensu em Direito Processual da UERJ

Patrono: José Carlos Barbosa Moreira. ISSN 1982-7636. pp. 550-579 http://www.e-publicacoes.uerj.br/index.php/redp/index

Para Silvio Roberto Mello Moraes ${ }^{35}$

O Defensor Público, como agente político do Estado, deve pautar sua vida, pública e particular, pela correição, serenidade e honestidade, zelando, sempre pelo prestígio da Justiça e preservando o bom nome da Instituição. Deve ainda velar pela dignidade de suas funções, sempre tendo em mente que não pode deixar de cumprir os deveres que lhe são impostos pela Constituição Federal e pelas Leis, nem renunciar a qualquer parcela de seus poderes ou prerrogativas que lhe foram conferidos. Isto porque os deveres, poderes $\mathrm{e}$ prerrogativas não lhe são outorgados em consideração pessoal, mas sim, para serem utilizados em benefício daqueles que o Defensor Público tem o dever de assistir. Descumpri-los ou renunciá-los será o mesmo que desconsiderar a incumbência que aceitou ao empossarse no cargo de Defensor Público.

Outrossim, foram previstos deveres e responsabilidades aos membros da Defensoria Pública pelo Novo Código de Processo Civil. Tais deveres são oriundos especialmente do princípio da boa-fé processual, que impõe o tratamento digno entre os sujeitos processuais, com respeito mútuo e tratamento sério do processo constitucional-civil.

Assim, o art. $5^{\circ}$ do NCPC anuncia que "aquele que de qualquer forma participa do processo deve comportar-se de acordo com a boa-fé". Brota daí o dever de agir subjetivamente de boa-fé (não exercitar atos dolosamente de má-fé), assim como respeitarse objetivamente as exigências de ordem ético-jurídica-processual. Nas palavras de Judith Martins-Costa ${ }^{36}$, "decorre de a boa-fé, em sua acepção objetiva, uma norma de conduta que impõe aos participantes da relação obrigacional um agir pautado pela lealdade, pela consideração dos interesses da contraparte".

Doutrinam sobre a boa-fé processual Humberto Teodoro Jr. et $a l^{37}$.

\footnotetext{
${ }^{35}$ MORAES, Silvio Roberto Mello. Princípios institucionais da Defensoria Pública - Lei Complementar 80, de 12.1.1994 anotada. São Paulo: Revistas dos Tribunais, 1995, p. 104-105.

${ }^{36}$ MARTINS-COSTA, Judith. Comentário ao Novo Código Civil. v. V, t. I. 2. ed. Rio de Janeiro: Forense, 2006, p. 42.

${ }^{37}$ BAHIA, Alexandre Melo Franco; NUNES, Dierle; PEDRON, Flávio Quinaud; THEODORO JR., Humberto. Novo CPC: fundamentos e sistematização. Rio de Janeiro: Forense, 2015, p. 163.
} 
Revista Eletrônica de Direito Processual - REDP. Volume 16. Julho a dezembro de 2015

Periódico Semestral da Pós-Graduação Stricto Sensu em Direito Processual da UERJ

Patrono: José Carlos Barbosa Moreira. ISSN 1982-7636. pp. 550-579 http://www.e-publicacoes.uerj.br/index.php/redp/index

Tal princípio no campo processual tem como destinatários

todos os sujeitos processuais e não somente as partes, alcançando juízes e tribunais.

Ele se torna uma das grandes premissas do processo cooperativo/comparticipativo encampado pelo Novo CPC, de modo a estabelecer um diálogo transparente e eficiente entre os sujeitos processuais, com assunção plena de responsabilidades, mas vedando o comportamento que infrinja as finalidades da atividade processual.

A violação à boa-fé processual, seja ela subjetiva ou objetiva, enseja conduta que deve ser coibida por todo o ordenamento jurídico, tanto é assim que o NCPC assim o fez, prevendo punições para aqueles que a violarem.

Partindo da premissa supra, o art. 77 do Novo Código de Processo Civil ${ }^{38}$ delineia,

\footnotetext{
${ }^{38}$ Art. 77. Além de outros previstos neste Código, são deveres das partes, de seus procuradores e de todos aqueles que de qualquer forma participem do processo:

I - expor os fatos em juízo conforme a verdade;

II - não formular pretensão ou de apresentar defesa quando cientes de que são destituídas de fundamento;

III - não produzir provas e não praticar atos inúteis ou desnecessários à declaração ou à defesa do direito;

IV - cumprir com exatidão as decisões jurisdicionais, de natureza provisória ou final, e não criar embaraços à sua efetivação;

$\mathrm{V}$ - declinar, no primeiro momento que lhes couber falar nos autos, o endereço residencial ou profissional onde receberão intimações, atualizando essa informação sempre que ocorrer qualquer modificação temporária ou definitiva;

VI - não praticar inovação ilegal no estado de fato de bem ou direito litigioso.

$\S 1^{\circ}$ Nas hipóteses dos incisos IV e VI, o juiz advertirá qualquer das pessoas mencionadas no caput de que sua conduta poderá ser punida como ato atentatório à dignidade da justiça.

$\S 2^{\circ} \mathrm{A}$ violação ao disposto nos incisos IV e VI constitui ato atentatório à dignidade da justiça, devendo o juiz, sem prejuízo das sanções criminais, civis e processuais cabíveis, aplicar ao responsável multa de até vinte por cento do valor da causa, de acordo com a gravidade da conduta.

$\S 3^{\circ}$ Não sendo paga no prazo a ser fixado pelo juiz, a multa prevista no $\S 2^{\circ}$ será inscrita como dívida ativa da União ou do Estado após o trânsito em julgado da decisão que a fixou, e sua execução observará o procedimento da execução fiscal, revertendo-se aos fundos previstos no art. 97.

$\S 4^{\circ} \mathrm{A}$ multa estabelecida no $\S 2^{\circ}$ poderá ser fixada independentemente da incidência das previstas nos arts. $523, \S 1^{\circ}$, e $536, \S 1^{\circ}$.

$\S 5^{\circ}$ Quando o valor da causa for irrisório ou inestimável, a multa prevista no $\S 2^{\circ}$ poderá ser fixada em até 10 (dez) vezes o valor do salário-mínimo.

$\S 6^{\circ}$ Aos advogados públicos ou privados e aos membros da Defensoria Pública e do Ministério Público não se aplica o disposto nos $\S \S 2^{\circ}$ a $5^{\circ}$, devendo eventual responsabilidade disciplinar ser apurada pelo respectivo órgão de classe ou corregedoria, ao qual o juiz oficiará.

$\S 7^{\circ}$ Reconhecida violação ao disposto no inciso VI, o juiz determinará o restabelecimento do estado anterior, podendo, ainda, proibir a parte de falar nos autos até a purgação do atentado, sem prejuízo da aplicação do § $2^{\circ}$.

$\S 8^{\circ} \mathrm{O}$ representante judicial da parte não pode ser compelido a cumprir decisão em seu lugar.
} 
Revista Eletrônica de Direito Processual - REDP. Volume 16. Julho a dezembro de 2015

Periódico Semestral da Pós-Graduação Stricto Sensu em Direito Processual da UERJ

Patrono: José Carlos Barbosa Moreira. ISSN 1982-7636. pp. 550-579 http://www.e-publicacoes.uerj.br/index.php/redp/index

exemplificativamente, alguns deveres processuais que devem ser seguidos pelos sujeitos do processo, sob pena de sanções previamente expostas, entre as quais se encontram multas de até vinte por cento do valor da causa, podendo tal valor ser aumentado até o máximo de dez salários mínimos, sanções cíveis (perdas e danos) e criminais.

Contudo, em conformidade com o art. $77, \S 6^{\circ}$, do NCPC, tais penas não se aplicam aos membros da Defensoria Pública, pois, considerando a autonomia da instituição, a violação à boa-fé processual deve ser apurada dentro do próprio órgão ao qual o Defensor Público faz parte, devendo o juiz oficiar a corregedoria respectiva para que seja realizada essa verificação.

Ressalte-se que além da responsabilização administrativa do Defensor Público perante sua instituição, deve este ainda ser regressivamente responsabilizado quando atuar com dolo ou fraude, nos termos do art. 186 do Novo $\mathrm{CPC}^{39}$.

Ainda, quando o Defensor Público der causa a adiamento ou repetição de atos processuais necessários, deverá este arcar com as despesas decorrentes. Nesse caso, deve-se verificar se tal fato decorreu de violação à boa-fé objetiva. Esse custeio encontra-se no artigo 93 do Novo CPC:

Art. 93. As despesas de atos adiados ou cuja repetição for necessária ficarão a cargo da parte, do auxiliar da justiça, do órgão do Ministério Público ou da Defensoria Pública ou do juiz que, sem justo motivo, houver dado causa ao adiamento ou à repetição.

Conclui-se, desta forma, que além do dever ético-administrativo, o Defensor Público possui o dever jurídico-processual de atuar em conformidade com a boa-fé, de modo a resguardar os interesses de seus assistidos, promovendo o processo civil de forma cooperativa com os demais sujeitos processuais, sob pena de incursão em sanções administrativas e processuais específicas.

\section{CONCLUSÃO}

\footnotetext{
${ }^{39}$ Art. 187. O membro da Defensoria Pública será civil e regressivamente responsável quando agir com dolo ou fraude no exercício de suas funções.
} 
Revista Eletrônica de Direito Processual - REDP. Volume 16. Julho a dezembro de 2015

Periódico Semestral da Pós-Graduação Stricto Sensu em Direito Processual da UERJ

Patrono: José Carlos Barbosa Moreira. ISSN 1982-7636. pp. 550-579 http://www.e-publicacoes.uerj.br/index.php/redp/index

A Defensoria Pública, como instituição constitucionalmente prevista para a defesa dos necessitados (artigos 5, LXXIV e 134, da Constituição da República de 1988), vem se solidificando como entidade essencial à justiça e fincando suas raízes por todo o emaranhado jurídico nacional. Assim, previsões legislativas isoladas na Lei Orgânica da Defensoria Pública (Lei Complementar $n^{\circ}$ 80/1994) estão cada vez mais detalhadas e espalhadas nas leis que organizam e ordenam o Estado Democrático Brasileiro.

Com o advento do Novo Código de Processo Civil (Lei 13.105/2015) a Defensoria Pública ganhou local de destaque dentro do diploma reitor dos procedimentos e formas que envolve todo o Judiciário, elevando ainda mais a carreira defensorial, participando, assim, ativamente da formação e condução dos processos judiciais. Em que pese alguns dispositivos já existirem no ordenamento jurídico pretérito, incorporaram-se diversas novidades ao texto legal, ampliando o espectro de atuação da Defensoria Pública.

A previsão de um capitulo exclusivo para a Defensoria Pública dentro do livro sobre sujeitos do processo é o reconhecimento da autonomia da instituição na condução processual, garantindo-se-lhe independência.

O reconhecimento da Defensoria Pública como titular da função de curadoria especial outorga à instituição o dever da garantia de defesa do contraditório e da legalidade nas ações judiciais em que se encontram indivíduos hipossuficientes juridicamente, seja por não serem encontrados para responder à demanda diante de citação ficta, seja por de indivíduos que, pela condição especial que se encontram, não tem como promover a defesa de seus interesses.

A codificação de prerrogativas próprias à atuação judicial da Defensoria Pública (tais como prazo em dobro em todas as suas manifestações, intimação pessoal com vista dos autos, intimação pessoal dos assistidos para providenciarem medidas necessárias ao andamento do processo e de testemunhas para comparecimento em audiência) fornece aparato jurídico para que seja efetuado serviço qualificado, aumentando assim a eficiência.

Ainda, ao dispor sobre a responsabilização administrativa e cível do membro da Defensoria Pública, subsidia a proteção ao princípio da boa-fé, implicando-se a cooperação e comparticipação entre a Defensoria Pública e as demais instituições consideradas sujeitos do processo, para que se possa fornecer a contento a satisfação dos direitos daqueles que necessitam. 
Revista Eletrônica de Direito Processual - REDP. Volume 16. Julho a dezembro de 2015

Periódico Semestral da Pós-Graduação Stricto Sensu em Direito Processual da UERJ

Patrono: José Carlos Barbosa Moreira. ISSN 1982-7636. pp. 550-579 http://www.e-publicacoes.uerj.br/index.php/redp/index

Conclui-se que a publicação do NCPC não põe fim às controvérsias processuais existentes, muito menos é ponto pacífico na discussão atual, contudo, no que tange à atuação da Defensoria Pública dentro do processo judicial cível, evoluiu de forma significativa, merecendo os devidos aplausos.

\section{REFERÊNCIAS BIBLIOGRÁFICAS}

ASSOCIAÇÃO NACIONAL DOS DEFENSORES PÚBLICOS (ANADEP). Parecer da comissão instituída pela Associação Nacional dos Defensores Públicos para Análise do Projeto do Novo Código de Processo Civil. Brasília, 2012. p. 17-18. Disponível em: $<$ http://www.anadep.org.br/wtksite/cms/conteudo/14949/Relat_rio_CPC_ANADEP_final_ 30_07.pdf $>$ Acesso em: 08 de março de 2015.

BAHIA, Alexandre Melo Franco; NUNES, Dierle; PEDRON, Flávio Quinaud; THEODORO JR., Humberto. Novo CPC: fundamentos e sistematização. Rio de Janeiro: Forense, 2015.

BRASIL. Código de processo civil: histórico da lei. Volume I. Tomo I. SENADO FEDERAL: $1974 . \quad$ Disponibilizado em: http://www2.senado.leg.br/bdsf/bitstream/handle/id/177828/CodProcCivil\%201974.pdf?se quence $=4$. Acesso em: 08 de março de 2015.

CUNHA, Leonardo José Carneiro da; DIDIER JR, Fredie. Comentário ao artigo 134. In. CANOTILHO, J. J. Gomes; MENDES, Gilmar F.; SARLET, Ingo W.; STRECK, Lênio L. (Coords.). Comentários à Constituição do Brasil. São Paulo: Saraiva/Almedina, 2013.

DINAMARCO, Cândido Rangel. Instituições de Direito Processual Civil. V. III. 4. ed. São Paulo: Malheiros, 2004.

LIMA, Frederico Rodrigues Viana de. Defensoria Pública. 3. ed. Salvador: Juspodivm, 2014.

MARTINS-COSTA, Judith. Comentário ao Novo Código Civil. v. V, t. I. 2. ed. Rio de Janeiro: Forense, 2006.

MORAES, Silvio Roberto Mello. Princípios institucionais da Defensoria Pública - Lei

Complementar 80, de 12.1.1994 anotada. São Paulo: Revistas dos Tribunais, 1995.

NERY JR., Nelson; NERY, R. M. de A. Código de processo civil comentado. 5. ed. São Paulo: RT, 2001. 